\title{
Onion Leaf Blight Caused by Xanthomonas campestris: Alternative Hosts and Resistant Onion Genotypes
}

\author{
Leonard W. O’Garro and Litta P. Paulraj, Microbial Pathogenicity Research Group, Department of Biology, \\ University of the West Indies, P.O. Box 64, Bridgetown, Barbados
}

\begin{abstract}
O'Garro, L. W., and Paulraj, L. P. 1997. Onion leaf blight caused by Xanthomonas campestris: Alternative hosts and resistant onion genotypes. Plant Dis. 81:978-982.

Tomato (Lycopersicon esculentum), pepper (Capsicum annuum), corn (Zea mays), French bean (Phaseolus vulgaris), soybean (Glycine max), winged bean (Psophocarpus tetragonolobus), lima bean (Phaseolus lunatus), field pea (Pisum sativum), moth bean (Phaseolus aconitifolins), and heliconia (Heliconia bihai) were evaluated as alternative hosts of Xanthomonas campestris, the causal agent of a leaf blight of onion (Allium cepa). On legumes, bacterial growth occurred in planta, and visible disease symptoms developed. From 19 commercial onion genotypes screened for leaf blight resistance, two cultivars, H-942 and H-508, were generally free of symptoms and had restricted bacterial growth in planta. These are the first known reports on alternative hosts of the bacterium and on resistance in onion to leaf blight.
\end{abstract}

Leaf blight of onion (Allium cepa L.), caused by Xanthomonas campestris, is a serious disease in Barbados $(4,6)$. The disease recently appeared on the neighboring islands of St. Christopher and Nevis, where onion production is increasing. Onion output is expanding on several other East Caribbean islands, and there is concern that leaf blight will eventually limit production. No onion genotype conferring high levels of resistance to the disease is grown on the islands.

Efforts to control leaf blight with sprays of copper- or zinc-based bactericides, including cuprasan, manzate, champion, and vandozeb, are generally ineffective in Barbados (5). Failure of chemical control has focused attention on alternative disease control measures, notably resistant onion genotypes and crop rotation. The present study reports on alternative hosts of the bacterium and resistance in onion to the leaf blight.

\section{MATERIALS AND METHODS}

Pathogen culture. $X$. campestris strains G6e, F58A12, and W4m were used routinely in this study. Each strain was derived from isolates obtained from diseased onion in Barbados. The original strains were characterized by cellular fatty acid composition and by other biochemical and

Corresponding author: L. W. O'Garro

Accepted for publication 23 April 1997.

Publication no. D-1997-0708-01R

(C) 1997 The American Phytopathological Society physiological tests (6). Strains F58A12 and G6e were resistant to streptomycin at 100 $\mu \mathrm{g} \mathrm{ml}{ }^{-1}$, rifampicin at $30 \mu \mathrm{g} \mathrm{ml}^{-1}$, and ampicillin at $50 \mu \mathrm{g} \mathrm{ml}^{-1}$ of nutrient agar medium. Strain W4 was resistant to the antibiotics as above, as well as to tetracycline at $10 \mu \mathrm{g} \mathrm{ml}^{-1}$ nutrient agar. Antibiotic resistance was obtained by plating bacteria from purified cultures of the original strains onto nutrient agar (Difco Laboratories, Detroit, MI) amended with a single antibiotic and recovering survivors. Survivors were plated onto a medium with a different antibiotic. The process was repeated using survivors from each antibiotic treatment to eventually produce strains resistant to the combinations of antibiotics. The antibiotic-resistant strains were as virulent on onion as were the originally isolated strains (unpublished data). The antibiotic-resistant strains and the original strains were also identical with respect to a number of physiological and biochemical characteristics previously described (6). The bacterium was routinely cultured on nutrient agar or in nutrient broth (Difco). Inoculum was prepared by growing bacteria overnight in nutrient broth at 28 to $30^{\circ} \mathrm{C}$ on a rotary shaker at 220 oscillations per minute. Bacteria were collected by centrifugation at $10,000 \times g$ for $10 \mathrm{~min}$, and pellets were washed twice and resuspended in sterile distilled water (SDW). The suspension was diluted to $5.5 \times 10^{8}$ cells $\mathrm{ml}^{-1}\left(\mathrm{OD}_{600}=0.46\right)$, and inoculum containing $10^{6}$ cells $\mathrm{ml}^{-1}$ was prepared by appropriate dilution.

Tests on potential alternative hosts. Tomato (Lycopersicon esculentum Mill.) cv. Walter, pepper (Capsicum annuum L.) cv. Calwonder 300 TMR, corn ( Zea mays L.) cv. Pioneer, French bean (Phaseolus vulgaris L.) cv. Green Crop, soybean (Glycine $\max ($ L.) Merr.) cv. Davis, and unknown cultivars of winged bean (Psophocarpus tetragonolobus (L.) DC.), lima bean (Phaseolus lunatus L.), field pea (Pisum sativum L.), moth bean (Phaseolus aconitifolins Jacq.), and heliconia (Heliconia bihai L.) were tested as potential hosts of $X$. campestris from onion. Plants were grown singly in pots $(10 \times 10 \mathrm{~cm})$ containing sterilized potting compost (Yates, New Zealand) in a growth chamber set at 26 to $28^{\circ} \mathrm{C}, 85$ to $95 \%$ relative humidity, and a 12-h photoperiod from fluorescent lamps providing light intensity of 1,020 $\mu \mathrm{E} \cdot \mathrm{s}^{-1} \cdot \mathrm{m}^{-2}$.

Abaxial and adaxial leaf surfaces on 7 or 8-week-old plants were inoculated by spraying to runoff with a hand-held sprayer that delivered a fine mist onto foliage from a distance of 30 to $45 \mathrm{~cm}$. Control plants were sprayed with SDW. Three plants each of tomato, pepper, corn, French bean, winged bean, soybean, and heliconia were inoculated with each onion strain of $X$. campestris. Both inoculated and control plants were kept in a growth chamber as described above, misted at 8-h intervals for 10 min with tap water to provide high humidity, and observed daily for symptoms.

From arbitrarily selected symptomatic tissues on inoculated plants, sections were excised and surface-disinfested by washing in $95 \%$ ethanol and $1.25 \%$ sodium hypochlorite solution for $10 \mathrm{~s}$ each, followed by rinses in SDW. Each section was then homogenized in 50 to $100 \mu \mathrm{l}$ of SDW with a sterile mortar and pestle. Loopfuls of the homogenate were streaked directly onto nutrient agar, and the streaks were observed for bacterial growth. Sections from symptomatic tissues on control plants were similarly processed, and homogenates were streaked onto nutrient agar and potato dextrose agar (Difco) for isolation of bacteria and fungi, respectively. Fungi were identified from morphological features (3), and bacteria were identified using procedures outlined by Schaad (7). Ten randomly selected colonies of each suspect pathogen from each affected potential host genotype were retained for pathogenicity tests. The experiment was conducted three times on different occasions. 
In other tests, intercellular spaces of the two youngest fully expanded leaves on each test plant of French bean, winged bean, soybean, lima bean, moth bean, field ringe (without needle) infiltration (8) of a suspension containing $4.0 \times 10^{4}$ cells $\mathrm{ml}^{-1}$ of $X$. campestris $\mathrm{W} 4 \mathrm{~m}$. Plants of each genotype serving as controls were similarly treated with SDW. Three plants of each genotype were tested. Immediately after infiltration, two $20 \mathrm{~mm}^{2}$ leaf disks were excised from within the infiltrated area of each of three randomly selected leaves. Leaf disks were surface-disinfested and comminuted in $100 \mu \mathrm{l}$ of SDW as described above. Liquid from the homogenate was diluted in serial 10-fold steps, and $100 \mu \mathrm{l}$ from each dilution was plated in triplicate onto nutrient agar. Colony counts were used to determine populations of bacteria. Identical leaf assays were made at daily intervals for 7 days. The test was conducted three times. For comparison, French bean leaves were infiltrated with a strain of $X$. campestris pv. phaseoli initially isolated from local field-grown beans with common blight symptoms.

Leaves were assayed and bacterial growth was determined exactly as described above.

Susceptibility of potential hosts grown in a cropping rotation with diseased onion was also tested in the field. Field plots located in Biology Park of the Cave Hill Campus of the University of the West Indies on Barbados were originally forest, but the land had been in grass pasture since 1980. The land was tilled and the soil was pea, or heliconia were inoculated by sy-

formed into four 8-m-long beds $80 \mathrm{~cm}$ wide and $30 \mathrm{~cm}$ apart. Yellow Granex onion was direct-seeded into the raised soil beds. This onion cultivar was previously shown to be susceptible to the leaf blight of onion (6). Four weeks after emergence, three beds of seedlings were each sprayinoculated with a suspension containing $10^{6}$ cells $\mathrm{ml}^{-1}$ of $X$. campestris strains F58A12, G6e, or W4 to induce leaf blight. One bed of onion seedlings was sprayed with SDW as a control. Two weeks later and after leaf blight symptoms developed on inoculated plants, the onion plants, including controls, were plowed into soil beds. Seeds of rotational and potential host crops, namely French bean, soybean, winged bean, moth bean, and field pea, were sown directly into infested soil 1 week later. The soil bed into which uninoculated onion seedlings were plowed was used to culture plants of these genotypes serving as controls. Plantings in each bed were arranged in a random design with three replicates, and each replicate consisted of six plants. After emergence, the rotational crops were misted with tap water for $10 \mathrm{~min}$ at $1000 \mathrm{~h}$ and $1630 \mathrm{~h}$ daily over a 12-week period. The misting device (Ofe International Inc., Miami, FL) was installed $5.5 \mathrm{~m}$ from soil beds so that plants were wet with tiny water droplets but there was generally little or no runoff. Plants were also sprayed every 2 to 3 weeks with the systemic fungicide triforine (Saprol, Caribbean Chemicals and Agencies Ltd., Trinidad and Tobago) to control fungal diseases. Plants were observed daily for symptoms of bacterial disease. The experiment was conducted three times, from

Table 1. Severity of leaf blight on yellow onions artificially inoculated with Xanthomonas campestris in field and laboratory tests

\begin{tabular}{lcccc}
\hline & & \multicolumn{3}{c}{ Disease severity $^{\mathbf{b}}$} \\
\cline { 4 - 5 } $\begin{array}{l}\text { Onion } \\
\text { cultivar }\end{array}$ & $\begin{array}{c}\text { Seed } \\
\text { source }\end{array}$ & Laboratory & Test 1 & Field $^{\mathbf{c}}$ \\
\cline { 3 - 5 } H-8 & 2 & 44.8 & $\ldots$ & 29.2 \\
Z-204 & 1 & 44.1 & 11.2 & 16.3 \\
Arad & 2 & 43.8 & 15.8 & $\ldots$ \\
H-891 & 2 & 31.9 & $\ldots$ & 28.6 \\
Z-218 & 1 & 31.2 & 19.8 & $\ldots$ \\
H-814 & 2 & 27.7 & 24.1 & 27.2 \\
Cebolla Texas & 3 & 26.9 & $\ldots$ & 28.3 \\
PSX-2789 & 2 & 21.9 & 16.0 & 13.2 \\
H-489 & 2 & 20.0 & $\ldots$ & 16.1 \\
H-95 & 2 & 19.3 & 23.2 & 21.7 \\
H-811 & 2 & 19.4 & 22.1 & 24.2 \\
Cebolla Roja & 3 & 17.6 & 9.6 & 12.3 \\
Grand Stand & 2 & 14.7 & 19.3 & 12.6 \\
H-9 & 2 & 12.9 & 15.5 & 15.3 \\
H-944 & 2 & 11.6 & 13.8 & 12.1 \\
H-675 & 2 & 11.4 & 19.6 & 0 \\
H-763 & 2 & 6.9 & $\ldots$ & 0 \\
H-508 & 2 & 3.0 & 0 & 8.2 \\
H-942 & 2 & 14.1 & 0 & \\
\multicolumn{1}{c}{ LSD (5\%) } & & 5.9 & \\
\hline
\end{tabular}

a Seed obtained from: 1 = Neuman Seed Co., El Centro, CA; 2 = Hazera Seed Co. Haifa, Israel; and $3=$ Peto Seed Co., Saticoy, CA.

${ }^{\mathrm{b}}$ Assessed as percent diseased leaf area 1 to 2 weeks after inoculation with Xanthomonas campestris. c $\ldots=$ missing due to poor germination of seeds.
1992 to 1995, each time at a different site in Biology Park, during the annual dry season from November to June. Rainfall and temperature were monitored at the experimental sites.

From infected field-grown plants, sections of symptomatic tissues were excised and assayed as described before except that homogenates were streaked directly onto nutrient agar amended with antibiotics appropriate for selection of the different mutants of $X$. campestris. Control plants bearing symptoms were assayed for fungi or bacteria as described before. Ten representative colonies from each rotational host genotype were retained for additional characterization (6).

A total of 240 presumptive $X$. campestris strains obtained from alternative hosts in field or laboratory tests were tested for pathogenicity on Yellow Granex. The surfaces of the two youngest fully extended leaves were pricked with sterile pins bearing bacterial matrix from 10-day-old cultures on nutrient agar (6). Leaves of control plants were similarly treated except that SDW replaced the bacteria matrix. All treated plants were kept in humid conditions in a plant growth chamber and observed for symptoms daily.

Because erwinias were isolated from some test plants, tests were made to evaluate any symptoms associated with the bacterium. Foliage of 7-week-old soybean and French bean plants was spray-inoculated with erwinias isolated from French bean or soybean. Inoculum was suspended in SDW at a concentration of $10^{6}$ cells $\mathrm{ml}^{-1}$. Inoculation methods and conditions were as previously described. Inoculated plants were misted at 8 -h intervals for $10 \mathrm{~min}$ and observed daily for symptoms. Ten Erwinia strains from French bean and 10 from soybean were tested on two replicates each with four plants of each host. The experiment was conducted twice.

Screening of onion cultivars. Nineteen commercial onion cultivars were tested in the laboratory and field for resistance to $X$. campestris (Table 1). One cultivar, Grand Stand, has been grown in Barbados as a leaf blight-tolerant genotype (4). For laboratory tests, each cultivar of onion was seeded, 100 per tray $(22 \times 16 \mathrm{~cm})$, into sterilized potting compost (Yates, New Zealand) and grown in a controlled-environment chamber with conditions as those described for culture of potential hosts. Leaves of 8-week-old plants were inoculated by spraying to runoff with a suspension containing $10^{6}$ cells $\mathrm{ml}^{-1}$ of $\mathrm{X}$. campestris strain F58A12. Plants serving as controls were sprayed with SDW. Treated plants, including controls, were kept in the growth chamber and were misted with tap water for 10 min every $8 \mathrm{~h}$. Each cultivar planting was replicated three times, and each replicate comprising 100 plants in trays was arranged randomly within the chamber. Plants were observed for disease 
symptoms 8 days after inoculation. Percent leaf area covered by lesions was measured and used to determine the mean disease severity per plant from measurements on 100 plants (6). The severity of disease for each cultivar was then determined as a mean of three replicates. Disease severity differences among cultivars were determined from analysis of variance (MSTAT; Michigan State University, East Lansing), and significance of differences between means was determined by LSD (5\%) values.

Resistance to the leaf blight was also assessed in the laboratory as extent of growth of $X$. campestris in onion leaves. The two youngest fully extended leaves on each of five plants of onion cultivars H-942, H508, and Yellow Granex were pin-prick inoculated at $1-\mathrm{cm}$ intervals with $X$. campestris strains F58A12 or G6e. Inoculated plants were maintained in a humid growth chamber as previously described. Leaf sections, each incorporating an inoculated area, were excised in sequence in a direction from the leaf tip toward the plant base shortly after inoculation and thereafter at 2-day intervals. Excised sections were surface-disinfected in $1.25 \%$ sodium hypochlorite solution for $5 \mathrm{~s}$, rinsed in SDW, and homogenized in $100 \mu \mathrm{l}$ of SDW with a mortar and pestle. Liquid from the homogenate was serially diluted in 10 -fold steps with SDW, and $100 \mu \mathrm{l}$ from each dilution was plated in triplicate onto nutrient agar. Cultures were incubated at 28 to $30^{\circ} \mathrm{C}$. Colonies from each leaf section at each sampling time were counted and averaged to determine mean bacterial growth on each plant. The experiment was conducted twice.

Onion resistance was also evaluated in bedded field plots located in the Biology Park as previously described. Seeds of onion cultivars were sown directly into two raised soil beds, each with plantings of onion genotypes (Table 1). After emergence, seedlings were thinned to $10 \mathrm{~cm}$ apart. Onion genotypes were arranged in a randomized design with five replications each containing 100 plants. Eight-week-old plants in one soil bed were inoculated by spraying leaves to runoff with a suspension containing $10^{6}$ cells $\mathrm{ml}^{-1}$ of $X$. campestris F58A12 or G6e in the morning when dew was present. Plants in the other soil bed were sprayed with SDW and served as controls. All treated plants were then misted with tap water for 15 min every $4 \mathrm{~h}$ and rated for leaf blight severity 2 weeks after inoculation as described previously (6). Disease severity for each cultivar was obtained as the mean of five replicates. Following analysis of variance, significant differences between means was determined by LSD $(5 \%)$ values. The experiment was conducted twice in 1992 to 1994, each time during October to February.
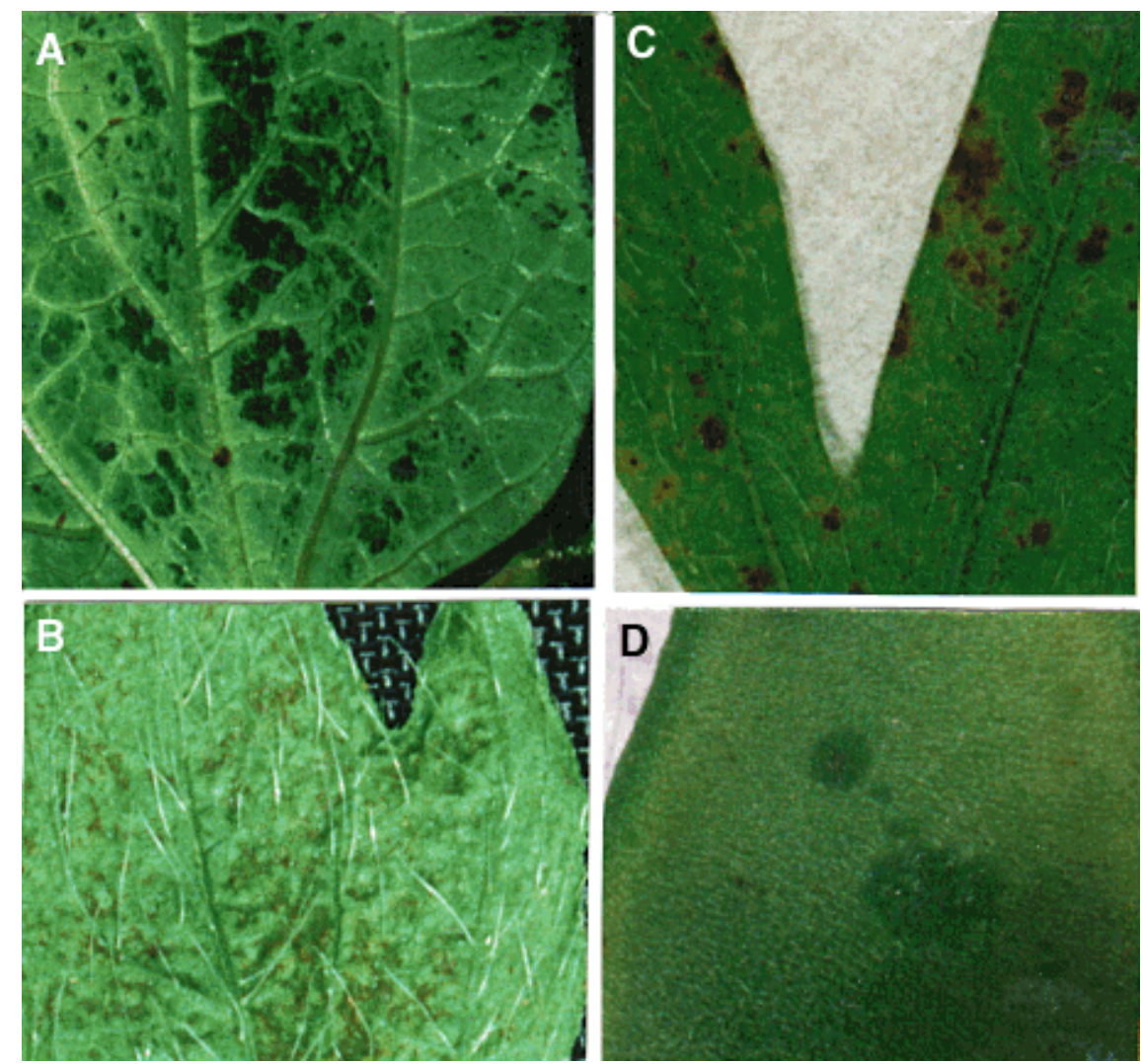

Fig. 1. Selected typical visible symptoms induced on legumes by onion strains of Xanthomonas campestris. (A and B) Water-soaking of abaxial leaf surface of French bean and winged bean, respectively. (C) Chlorosis and necrosis of moth bean leaf. (D) Water-soaked spots on pod of lima bean.

\section{RESULTS}

Susceptibility of potential hosts in laboratory tests. Disease symptoms appeared on French bean, winged bean, and soybean 6 to 8 days after spray-inoculation. Symptoms on French bean and winged bean appeared initially on the abaxial leaf surface as coalescing watersoaked lesions that became necrotic (Fig. $1 \mathrm{~A}$ and $\mathrm{B})$. On soybean, symptoms appeared on leaf margins either as regular cone-shaped yellow areas that progressed to intercostal sites of affected leaves or, less frequently, as diffused pale yellow borders that increased in width and also became necrotic. Pepper, tomato, corn, and heliconia were apparently unaffected by the strains of $X$. campestris from onion. None of the control plants had visible symptoms of disease with the exception of three soybean plants in one experiment on which margins of four older leaves turned yellow followed by varying degrees of necrosis.

All legumes infiltrated with $X$. campestris from onion developed symptoms of bacterial disease in the three tests conducted. Legumes inoculated with strain $\mathrm{W} 4 \mathrm{~m}$ showed varying degrees of watersoaking within 7 days. French bean and winged bean were most severely affected. In addition to water-soaking, French bean was defoliated by strain W4m and by $X$. campestris pv. phaseoli 8 days after infection. Tests assessing bacterial growth in inoculated legumes also gave similar results. As a consequence, bacterial growth in each legume was assessed as the mean of assessments from three tests (Fig. 2). In French bean leaves, populations of strains $\mathrm{W} 4 \mathrm{~m}$ and $X$. campestris pv. phaseoli increased over a 7-day period; but in heliconia, populations of W4m declined (Fig. 2). In other legumes, populations of W4m increased over time similar to French bean (data not shown). None of the legumes infiltrated with SDW developed symptoms of disease or appeared to be colonized by bacteria or fungi.

Susceptibility of potential hosts in field tests. At the experimental site, monthly rainfall ranged from 13.1 to 74.5 $\mathrm{mm}$, and day and night temperatures were 28.5 to $31.2^{\circ} \mathrm{C}$ and 21.1 to $24.5^{\circ} \mathrm{C}$, respectively, over the three dry seasons. Relative humidity at the site during the experiment varied from 62 to $84 \%$. With the exception of soybean, which failed to grow, all legumes grown in soil infested with antibiotic-resistant strains of $X$. campestris were affected by disease 5 to 8 weeks after planting. Water-soaked areas developed on abaxial surfaces and margins of leaves of French bean and lima bean. Winged bean, moth bean, and field pea developed circular or diffused areas of foliar chlorosis (Fig. 1C). Chlorotic areas in leaves increased in size and became necrotic. Small, raised necrotic spots developed on pods of moth bean, and spreading water-soaked 
lesions that became rough appeared on pods of lima bean (Fig. 1D). Marginal necrosis developed on five leaves from two of 18 noninoculated French bean plants 9 to 12 weeks after planting in one experiment. All other control plants were free of symptoms.

Reisolation of antibiotic resistant mutants. Isolation from symptomatic tissues of potential hosts inoculated in the laboratory or in the field with antibiotic-resistant strains of $X$. campestris generally yielded numerous colonies of yellow-pigmented bacteria resistant to the appropriate set of three antibiotics. These bacteria were also rod-shaped, gram-negative, oxidase-negative, urease-negative, and catalase-positive, and they produced acid from cellobiose, glucose, mannose, and trehalose. They were monotrichously flagellated and did not utilize asparagine as the sole source of carbon and nitrogen or reduce nitrates to nitrites. The bacteria hydrolyzed milk proteins, starch, and gelatin but not pectate. All bacteria tested for the presence of xanthomonadin pigments produced yellow spots of average $\mathrm{R}_{\mathrm{f}}$ value of 0.46 on silica gel thin layer chromatography plates. The bacteria were isolated most abundantly from at least 38 water-soaked lesions from leaves of French bean, winged bean, and lima bean; 13 water-soaked lesions from pods of lima bean; 18 sections with chlorosis from each of winged bean, moth bean, and field pea; 18 sections from yellow cone-shaped lesions on soybean leaf margins; 16 necrotic lesions from winged bean pods or leaves; and in relatively smaller amounts from an undetermined number of samples of advanced necrotic tissues of affected plants. On nonselective media, the most frequently isolated fungi were of the Aspergillus genus, and the most frequently isolated bacteria were characterized as strains of Erwinia. These strains were flagellated, rod-shaped facultative anaerobes that produced yellow-pigmented mucoid colonies on nutrient agar and acid from fructose, glucose, galactose, and sucrose. They did not produce xanthomonadins and were able to reduce nitrates and grow on Miller-Schroth medium (7). Erwinias were isolated most frequently from necrotic lesions on soybean and French bean control plants.

Pathogenicity tests of 240 yellow-pigmented bacterial strains isolated from lesions on legumes indicated all were capable of inducing water-soaking on Yellow Granex. Strains from each of the legumes were included in the collection. None of the French beans nor soybean plants developed symptoms from inoculations with any of 20 Erwinia strains.

Resistance in onion to leaf blight. The severity of leaf blight on onion cultivars tested in the field and laboratory is shown in Table 1. During field experiments, relative humidity varied from 67 to $82 \%$. Average daily temperature and monthly rainfall were 25.0 to $26.2^{\circ} \mathrm{C}$ and 51.4 to $84.7 \mathrm{~mm}$, respectively. The three laboratory tests conducted to assess disease severity gave similar results. Consequently, the results are presented as the mean disease severity of three tests. In laboratory tests, onion cultivars H-8, Z-204, Arad, H891, Z-218, and H-814 were significantly more severely affected by leaf blight than were cultivars H-9, H-944, H-675, H-763, $\mathrm{H}-508$, and H-942. The other onion genotypes were intermediate between these two groups of onion in the extent of blight symptoms observed. Results of the laboratory tests and the second of two field tests conducted were generally similar with respect to the grouping of onion genotypes based on susceptibility to the leaf blight (Table 1). In the other field experiment, the onion genotypes conformed less rigidly to the disease susceptibility grouping described above. In all cases, notably field tests, cultivars $\mathrm{H}-508$ and $\mathrm{H}-942$ were generally free of blight symptoms. All plants of each onion genotype serving as controls were apparently unaffected by blight.

Responses of cultivars H-942 and H-508 to $X$. campestris strains G6e or F58A12 introduced by needle inoculation appeared within $48 \mathrm{~h}$ as small, localized necrotic lesions coincident with points of inoculation. Lesions from needle inoculations on
Yellow Granex were extensive and produced complete water-soaking and general disintegration of leaves 7 to 8 days after inoculation.

In two tests assessing bacterial growth in inoculated Yellow Granex, H-942, and H502, each test gave similar results. As a result, the mean bacterial populations of two tests were determined and used to assess bacterial growth. Yellow Granex supported bacterial growth of $X$. campestris strain $\mathrm{W} 4 \mathrm{e}$; whereas the bacterial populations were significantly restricted in $\mathrm{H}-942$ and H-502 (Fig. 3). Growth of strain G6e on the same onion cultivars was similar (data not shown). None of the control test plants produced disease symptoms or evidence of bacterial colonization.

\section{DISCUSSION}

Determination that $X$. campestris can cause an economically important leaf blight of onion $(4,6)$ has led to investigations on alternatives for control. The reactions of onions to leaf blight were unknown, and the value of crop rotations in closely sequenced plantings was undetermined. The study was also prompted by reports of crop failure from farmers who planted French bean immediately following onion with leaf blight. Corn, pepper, tomato, and French bean are now grown in rotation with onion. Three xanthomonads,

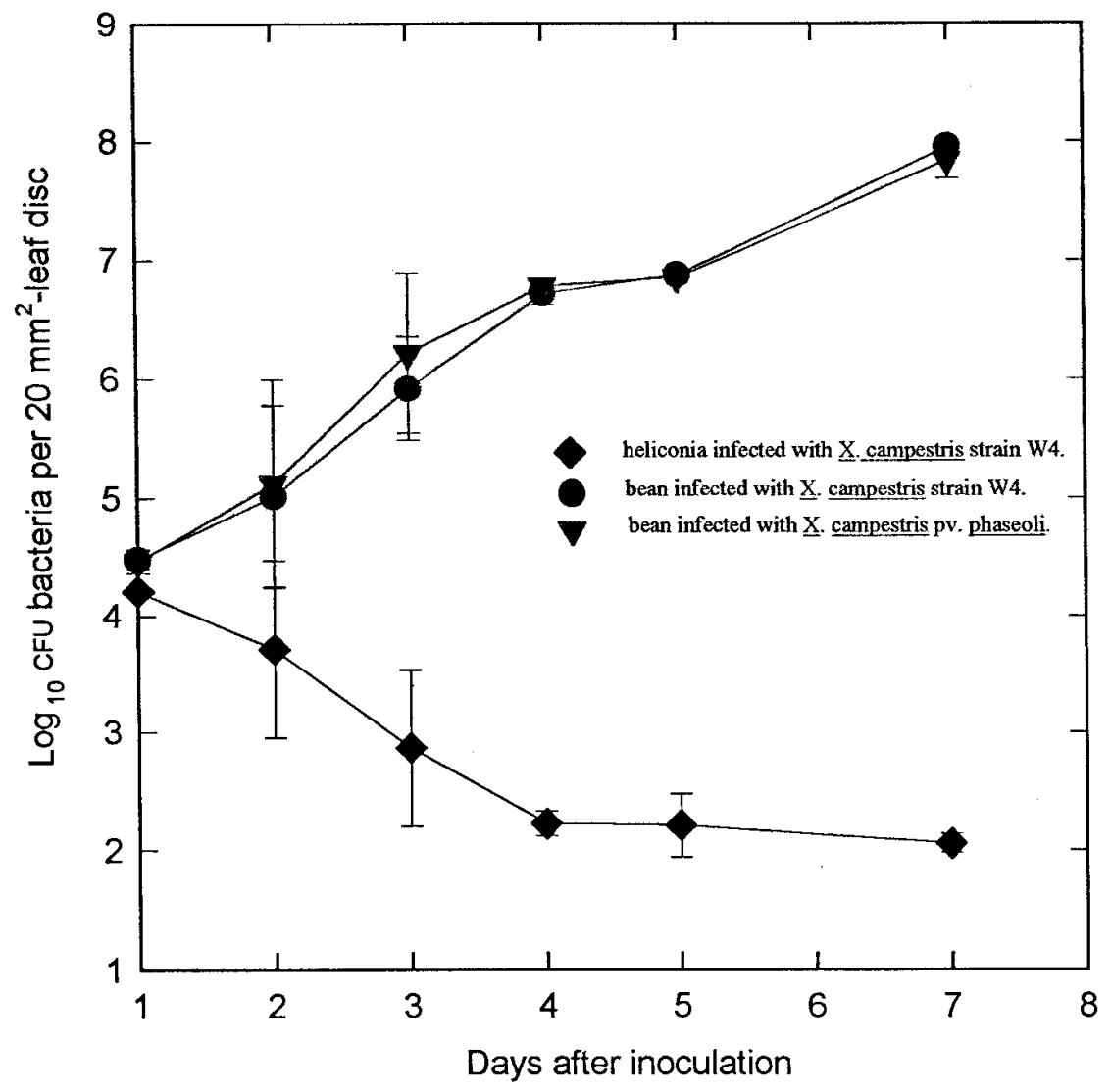

Fig. 2. Population changes in French bean and heliconia infiltrated with antibiotic-resistant Xanthomonas campestris. Values calculated from plate counts of bacteria in assays of $20 \mathrm{~mm}^{2}$ leaf disks represent means and standard errors (bars) for three tests. 


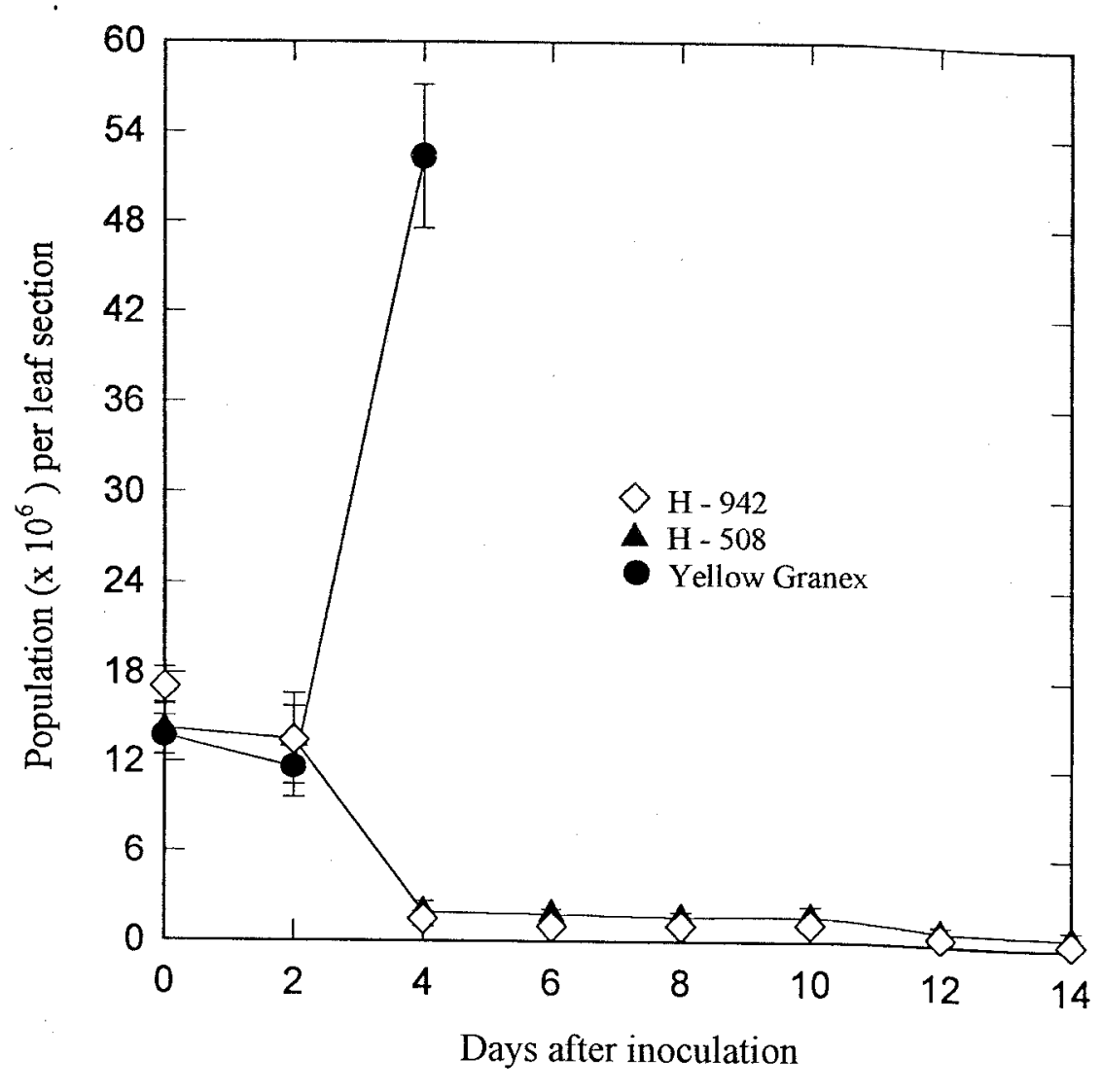

Fig. 3. Population changes of an antibiotic-resistant mutant of Xanthomonas campestris inoculated into leaves of onion cultivars Yellow Granex, H-508, and H-942. Values, calculated from plate counts in leafdisk assays, are the means and standard errors (bars) of two tests.

$X$. campestris pv. glycines, $X$. campestris pv. phaseoli and $X$. campestris pv. vignicola, all of which are pathogenic on species within Leguminosae (1), are most closely related to $X$. campestris from onion on the basis of fatty acid analysis $(4,6)$. The degree of relatedness between onion strains of $X$. campestris and these other xanthomonads was used as a basis for selecting some of the potential hosts in the present study. Moreover, all but winged bean are also reported as natural hosts of $X$. campestris pv. glycines and/or $X$. campestris pv. phaseoli (1). Tomato, pepper, and corn are nonlegume hosts of xanthomonads (1) less closely related to $X$. campestris from onion. For comparison, heliconia was selected as an example of a plant genotype not known to be a host of $X$. campestris (1).

The evidence from these studies suggests that French bean, soybean, winged bean, field pea, moth bean, and lima bean are hosts of $X$. campestris from onion on the basis of extensive bacterial growth in planta and induction of visible disease symptoms by the bacterium on foliage and/or pods. Moreover, a strain of X. campestris from onion and a strain of a known bean pathogen (X. campestris pv. phaseoli) affected French bean similarly. It would be to these bacteria.

$X$. campestris infection is favored in the laboratory by high relative humidity ( 85 to $95 \%$ ) and temperature ranging from 25 to $30^{\circ} \mathrm{C}$ (6). These conditions were used in laboratory tests of alternative hosts. In contrast, tests of alternative hosts in the field were generally conducted at temperatures and relative humidity below the optimal temperature and humidity for infection. Plant misting in the growth chamber was also different from misting in the field. It was assumed that the legumes were not unnaturally predisposed to infection by the bacterium under laboratory or field conditions.

$X$. campestris was detected from necrotic lesions on French bean and on soybean plants, but all of the symptoms on these plants may not have been induced by the xanthomonad only. Necrosis was also probably influenced by leaf senescence or other physiological characteristics since a few leaves of French bean and soybean control plants in one experiment were similarly affected in the absence of a de- tectable pathogen.

The onion industry on the East Caribbean islands is generally based on cultivation of the cultivar Grand Stand. This cultivar was introduced first to Barbados in 1986 to reduce the impact of leaf blight (4). Six years later, Grand Stand plantings had severe leaf blight. There is considerable need to introduce highly resistant onions. Of 19 onion genotypes evaluated in this study, cultivars H-942 and H-508 were least affected by leaf blight (Table 1). On the basis of this result, resistance was assessed by pathogen growth in planta. The rapid restriction of pathogen growth (Fig. 2 ), concomitant with induction of localized necrosis, is indicative of monogenic or oligogenic control of resistance in these cultivars (2).

The present study provides useful information on control of the leaf blight of onion caused by $X$. campestris. Of the plant genotypes evaluated as alternative hosts of the bacterium, only corn, pepper, tomato, and French bean are commonly rotated with onion on several East Caribbean islands.

French bean should not be in a close rotation with onions if the onions were infected with the leaf blight pathogen. This legume has potential to maintain inoculum of the pathogen, and the legume crops may suffer economic losses. Onion cultivars $\mathrm{H}$ 942 and H-502 appear resistant to leaf blight and should be evaluated further for possible introduction into Barbados.

\section{ACKNOWLEDGMENTS}

This research was supported by grants from the International Foundation for Science, University of the West Indies, Cave Hill Campus and Barclays Bank Development Fund in the Caribbean. We thank Cynthia Spooner for typing the manuscript.
LITERATURE CITED

1. Bradbury, J. F. 1986. Guide to Plant Pathogenic Bacteria. CAB International Mycological Institute, Slough, UK.

2. Collinge, D. B., and Sluzarenko, A. J. 1987. Plant gene expression in response to pathogens. Plant Mol. Biol. 9:389-410.

3. Domsch, K. H., Gams, W., and Anderson, T. 1980. Compendium of Soil Fungi. Vol. 1. Academic Press, London.

4. Paulraj, L. 1991. Epidemiology of a leaf blight of onion in Barbados. Ph.D. thesis. University of the West Indies.

5. Paulraj, L., and O'Garro, L. W. 1992. Aspects of the epidemiology of a leaf blight of onion in Barbados. Pages 89-96 in: 10th Annu. Proc. Barbados Soc. Technol. Agric.

6. Paulraj, L., and O'Garro, L. W. 1993. Leaf blight of onions in Barbados caused by Xanthomonas campestris. Plant Dis. 77:198-201.

7. Schaad, N. W., ed. 1980. Laboratory Guide for Identification of Plant Pathogenic Bacteria. American Phytopathological Society, St. Paul, MN.

8. Swanson, J., Kearney, B., Dahlbeck, D., and Staskawicz, B. 1988. Cloned avirulence gene of Xanthomonas campestris pv. vesicatoria complements race-change mutants. Mol. PlantMicrobe Interact. 1:5-9. 